\title{
DAMPAK KEKERASAN BAHASA PENDIDIK TERHADAP PSIKOLOGIS PESERTA DIDIK
}

\author{
Lis Susilawati \\ Program Studi Pendidikan Bahasa dan Sastra Indonesia \\ IKIP BUDI UTOMO MALANG \\ EMAIL: lhissusilawati@gmail.com
}

\begin{abstract}
It occurs frequently for many preceptorsconsider that this mien is the most effective one to control the protégé. Furthermore, it also aims to describe some factorsthat can trigger a verbal abuse, and then the last one is aimed to explain someverbal abuses that used by preceptor in teaching their protégé.This research figured out that the preceptor did seven kinds of verbalabuses, they are reprimanding the protégé, refusal, accusation, disparagement,judgment, forcefulness, and posing a threat. There are two causes of verbal abuse, they are the preceptor's lack of knowledge about an appropriate teaching andstudent's disobeying to the preceptors. Psychological effect of verbal abuse isdecreasing protégé's psychology. The evidences is that the protégé take a bow andfeel fear when they see the preceptor. Based on these finding, it is recommended for preceptor not to do verbalabuse. Moreover, the headmaster should supervise the class activity successively to increase the quality of the preceptors.
\end{abstract}

Keywords: Psycholgy impact, Verbal Violence, the learning

Akhir-akhir ini sering dijumpai peristiwa kekerasan diberbagai media publik, seperti berita mengenai puluhan peserta didik trauma sekolah akibat kekerasan Poelwali (2013). Juga berita mengenai kepala sekolah yang menganiaya peserta didiknya karena melompat dari kelas Rukmorini (2013), serta masih banyak beritaberita lainnya. Kekerasan adalah perilaku tidak layak yang mengakibatkan kerugian atau bahaya secara fisik, psikologis, atau finansial, baik yang dialami individu maupun kelompok Galtung (1990). Kekerasan yang terselubung didalam dunia pendidikan ini telah diupayakan untuk ditekan serendah mungkin oleh pemerintah dengan dikeluarkannya Undang-Undang No 23 tahun 2002 tentang perlindungan anak, namun dalam kenyataannya kekerasan masih sering dilakukan, para pelaku kekerasan berpendapat bahwa segala sesuatunya bisa diselesaikan atau dikendalikan dengan cara kekerasan.

Savitri (2012:4) mengatakan bahwa kekerasan dan penekanan akan berakibat anak menjadi tidak disiplin dan nakal. Berbeda dengan pendapat sebagian besar pendidik pelaku kekerasan yang berpendapat bahwa dengan melakukan kekerasan dan penekanan, maka para peserta didik akan disiplin serta patuh terhadap instruksi yang diberikan oleh pendidik. Menurut (Ronald C. Partin 2012), menyakiti peserta didik hanya akan menjauhkan peserta didik dari pendidiknya, ini berarti bahwa jika seorang pendidik melakukan kekerasan pada peserta didiknya maka peserta didik akan semakin menjauh dari pendidik. Kurangnya Menurut Undang-Undang Sistem Pendidikan Nasional (UU Sisdiknas)Nomor 20 Tahun 2003 Pasal 1 ayat (1) disebutkan bahwa pendidikan bertujuanagar peserta didik secara aktif mengembangkan potensi dirinya untuk memilikikekuatan spiritual keagamaan, pengendalian diri, kepribadian, kecerdasan, akhlakmulia, serta keterampilan yang diperlukan dirinya, masyarakat, bangsa dannegara. Berdasarkan UU Sisdiknas itu, jelas bahwa kekerasan bukan bagian danmetode tepat dalam pendidikan.Bentuk kekerasan pada peserta didik masih dianggap cara yang efektif untukmengendalikan peserta didik. Imania (2013) menyatakan berdasarkan data HotlineService Pengaduan dan Advokasi Pusat Data dan Informasi pada tahun 2005menyebutkan bahwa 4.9\% kekerasan fisik dilakukan oleh bapak pendidik dan $42.16 \%$ oleh ibu pendidik, kemudian temuan lainnya adalah perlakuan kekerasansecara psikis dilakukan oleh bapak pendidik sebesar $4.1 \%$ dan $6.2 \%$ oleh ibupendidik. Berdasarkan hasil penelitian yang dilakukan oleh UNICEF pada tahun2006, di beberapa daerah di Indonesia menunjukkan bahwa sekitar $80 \%$ kekerasan yang terjadi pada 
peserta didik dilakukan oleh pendidik. Kekerasan-kekerasan yang dilakukan oleh pendidik kepada peserta didik seperti dilemparpenghapus dan penggaris, dijemur dilapangan, dan dipukul. Disamping itu pesertadidik juga mengalami kekerasan psikis dalam bentuk bentakan dan kata makianseperti bodoh, goblok, kurus, jam karet dan sebagainya, Imania (2013).

Kekerasan yang dilakukan oleh pendidik sangat bertentangan dengannorma, dan perundangundangan. Pendapat Freedman dalam Pidarta (2007)yang menyatakan bahwa pendidik harus mampu membangkitkan kesanpertama yang positif dan tetap positif untuk hari-hari berikutnya. Sikap danperilaku pendidik sangat penting artinya bagi kemauan dan semangat belajaranak-anak. Hukuman yang dilakukan oleh pendidik akan menjadi kesan negatifyang berdampak negatif pula dalam proses belajar anak. Sekecil apapun dampakyang timbul terhadap praktek kekerasan dalam pendidikan, tetap saja hal iniadalah suatu kesalahan. Sekolah sepatutnya tempat bagi peserta didik untukberkembang. Namun, disaat kekerasan terjadi di sekolah, sekolah justrumematikan perkembangan psikologi peserta didik.

Sepanjang bulan Januari - Maret tahun 2007 terdapat 226 kasus kekerasanterhadap anak di sekolah. Jumlah ini meningkat dibandingkan dengan kwartalyang sama tahun lalu yang berjumlah 196. Ketua Umum Komisi Nasional(Komnas) Perlindungan Anak Seto Mulyadi mengatakan selama Januari-April2007 terdapat 417 kasus kekerasan terhadap anak. Rinciannya, kekerasanfisik 89 kasus, kekerasan seksual 118 kasus, dan kekerasan psikis 210 kasus,dari jumlah itu 226 kasus terjadi di sekolah. Data yang bisa dijadikanpertimbangan lagi adalah menurut Sekjen KPA, Arist Merdeka Sirait, padatahun 2009 telah terjadi aksi bullying atau kekerasan di sekolah sebanyak 472 kasus. Angka ini meningkat dari tahun 2008, yang jumlahnya sebanyak 362 kasus. Dari beberapa pemaparan data diatas bisa diketahui bahwa kekerasan masihsering dilakukan, terutama di linkup pendidikan. Itulah sebabnya penelitian inisangat penting bagi para pendidik.

Beberapa kasus kenakalan yang dilakukan oleh pesertadidik, dapat berakibat kurangnya minat peserta didik yang menjadi korban kekerasan ini dalam mengikuti pembelajaran di sekolah serta membuat peserta didik beranggapan bahwa dirinya "bodoh" (kata-kata yang sering diucapkan pendidik). Para peserta didik korban kekerasan dalam sekolah banyak mengalami gangguan psikis dalam dirinya hingga menimbulkan trauma dalam dirinya. Ini yang ketakutan ketika bertemu pendidik. Beberapa peserta didik perempuan yang memiliki mental lemah akan menangis ketika seorang pendidik yang melakukan tindak kekerasan kepada dirinya mendekat, hal ini diungkapkan secara terang-terangan tanpa rasa bersalah oleh pendidik yang melakukan tindakan kekerasan terhadap peserta didik tersebut. Perilaku-perilaku peserta didik ini diakibatkan trauma terhadap kekerasan yang sebelumnya pernah dilakukan.

\section{PEMBAHASAN}

\subsection{Kekerasan}

Abuse adalah kata yang bisa diterjemahkan menjadi kekerasan, penganiyaan, penyiksaan, atau perlakuan salah. Barker dalam buku Kekerasan terhadap anak mendefinisikan abuse sebagai "improper behavior intended to cause physical, psychological, or financial harm toan individual or group" (kekerasan adalah perilaku tidak layak yang mengakibatkan kerugian atau bahaya secara fisik, psikologis, atau finansial, baik yang dialami individu maupun kelompok), namun memaham ikekerasan tidak cukup dengan memahami definisinya saja. Adalah hal yang penting untuk juga memahami apa saja yang dikategorikan sebagai tindak kekerasan. Berdasarkan hal ini, Galtung (1990) mencoba menjawab dengan membagi tipologi kekerasan menjadi 3 (tiga), yaitu:

\subsubsection{KekerasanLangsung}

Kekerasan Langsung. Kekerasan langsung disebut juga sebagai sebuah peristiwa (event) dari terjadinya kekerasan.Kekerasan langsung terwujud dalam perilaku, misalnya: pembunuhan, pemukulan, intimidasi, penyiksaan. Kekerasan langsung merupakan tanggungjawab individu, dalam arti individu yang melakukan tindak kekerasan akan mendapat hukuman menurut ketentuan hokum pidana. 
2.1.2 KekerasanStruktural (kekerasan yang melembaga).

Disebutjugasebuah

proses

dariterjadinyakekerasan. Kekerasan structural terwujud dalam konteks, sistem, dan struktur, misalnya: diskriminasi dalam pendidikan, pekerjaan, pelayanan kesehatan. Kekerasan struktural merupakan bentuk tanggungjawab negara, dimana tanggung jawab adalah mengimplementasikan ketentuan konvensi melalui upaya merumuskan kebijakan, melakukan tindakan pengurusan.administrasi, melakukan pengaturan, melakukan pengelolaan dan melakukan pengawasan.Muaranya ada pada system hokum pidana yang berlaku.

\subsubsection{KekerasanKultural.}

Kekerasan kultural merupakan suatu bentuk kekerasan permanen. Terwujud dalam sikap, perasaan, nilai-nilai yang dianut dalam masyarakat, misalnya: kebencian, ketakutan, rasisme, ketidaktoleranan, aspek-aspekbudaya, ranahsimbolik yang ditunjukkan oleh agama dan ideologi, bahasa dan seni, serta ilmu pengetahuan. Sama dengan kekerasan struktural, kekerasan cultural merupakan bentuk tanggungjawab negara, dimana tanggungjawab adalah mengimplementasikan ketentuan konvensi melalui upaya merumuskan kebijakan, melakukan tindakan pengurusan.administrasi, melakukan pengaturan, melakukan pengelola .Muaranya ada pada system hokum pidana yang berlaku.

\subsection{DampakPsikologis}

Menurut Haryanto (2011) Psikologi berasal dari kata dalam bahasaYunani Psychology yang merupakan gabungan dan kata psyche dan logos. Psyche berartijiwa dan logos berartiilmu. Secara harafiah psikologi diartikan sebagai ilmu jiwa. Istilah psyche atau jiwa masih sulit didefinisikan karena jiwa itu merupakan objek yang bersifat abstrak, sulit dilihat wujudnya, meskipun tidak dapat dimungkiri keberadaannya. Dalam beberapa dasawarsa ini istilah jiwa sudah jarang dipakai dan d iganti dengan istilah psikis. Menurut Ensiklopedi Nasional Indonesia Jilid 13 (1990), Psikologi adalah ilmu yang mempelajari perilaku manusia dan binatang baik yang dapat dilihat secara langsung maupun yang tidak dapat dilihat secara langsung. Namun menurut Dakir dalam
(Aswaty. 2013), psikologi adalah ilmu yang membahas tingkah laku manusia dalam hu bungannya dengan lingkungannya. Serta pengertian Psikologi menurut MuhibbinSyah (2008), psikologi adalah ilmu pengetahuan yang mempelajari tingkah laku terbuka dan tert utup pada manusia baik selaku individu maupun kelompok, dalam hubungannya dengan 1 ingkungan. Tingkah laku terbuka adalah tingkah laku yang bersifat psikomotor yang meliputi perbuatan berbicara, duduk, berjalan dan lain sebagainya, sedangkan tingkah laku tertutup meliputi langsung berfikir, berkeyakinan, berperasaan.

\subsection{Bahasa}

Bahasa adalah sistem lambang bunyi yang arbitrer yang digunakan oleh ang gota kelompok sosial untuk bekerjasama, berkomunikasi, dan mengidentifikasikan diri Barber dalam (Chaer, 2009). Menurut Chaer, bahasa memiliki banyak pengertian dilihat dari segi sifat atau cirinya, yaitu; Bahasa sebagai sebuah system. Sistem berarti susunan teratur berpola yang membentuk suatu keseluruhan yang bermakna atau berfungsi.Sebagai sebuah system, bahasa itu sekaligus bersifat sistem atis dan sistemis. Dengan sistematis artinya, bahasa itu tersusun menurut suatu pola; tidak tersusun secara acak, secara sembarangan. Sedangkan sistemis artinya, bahasa itu bukan merupakan sistem tunggal, tetapi terdiri juga dari subsubsistem subsistemmorfologi, sub-sistem sintaksis, dan subsistem semantik. Bahasa itu berwujud lambing Bahasa adalah suatu sistem lambang dalam wujud bunyi- bahasa, bukan dalam wujud yang lain. Lambang menandai sesuatu yang lain secara konvensional, tidak secara alamiah dan langsung.

\section{Bahasa itu berupa bunyi}

Secara teknis, menurut Ketidaklaksana dalam Chaer (2009) bunyi adalah kesan pada pusat syaraf sebagai akibat dari getaran dari gendang telinga yang bereaksi karena perubahan-perubahan dalam tekanan udara. Bunyi ini bisaberasal dari mana saja seperti, kesekan, tabrakan, getaran, dan lainnya. Namun yang dimaksud dengan bunyi pada bahasa ialah bunyi yang berasal dari pita sura manusia,selain itu maka bukan termasuk bunyi bahasa. Hakikat bahasa itu merupakan bunyi, adalah dengan 
banyaknyabahasa dimuka bumi ini yang tidak memiliki bahasa tulis,karena bahasa-bahasa ini tidak atau belum mengenal sistem.

\section{Bahasa itu bersifat arbitrer}

Kata arbitrer bias diartikan sebagai sewenang-wenang,berubah-ubah, tidak tetap, mana suka. Yang dimaksudkandengan istilah arbitrer adalah tidak adanya hubungan wajibantara lambang bahasa (yang berwujud bunyi) dengankonsep atau pengertian yang dimaksudkan oleh lambangtersebut. Misalnya antara [kuda] dengan yangdilambangkannya yaitu "sejenis binatang berkaki empatyang biasa dikendarai". Kita tidak bias menjelaskan kenapabinatang itu dilambangkan dengan bunyi "kuda".

\section{Bahasa itu bermakna}

Beberapa pengertian sebelumnya mengatakan bahwa bahasa itu sebagai lambang yang berwujud bunyi. Maka yang dilambangkan itulah yang memiliki suatu makna atau pengertian, suatu konsep, ide, atau pikiran yang disampaikan dalam wujud bunyi. Oleh karena itulah bisa dikatakan bahwa bahasa itu memiliki makna. Maka, segala ucapan yang tidak memiliki makna dapat disebut bukanbahasa.

\section{Bahasa itu bersifat konfesional}

Meskipun hubungan antara lambang bunyi dengan yang dilambangkan bersifat arbitrer, tetapi pengunaan lambang tersebut untuk suatu konsep tertentu bersifat konvensional. Artinya, semua anggota masyarakat bahasa itu mematuhi konvensi bahwa lambang tertentu itu digunakan untukmewakili konsep yang mewakilinya. Misalnya binatang bersayap yang bias terbang itu secara arbitrer dinamakan"burung" maka masyarakat bahasa Indonesia harus mematuhinya.

\section{Bahasa itu bersifat unik}

Unik artinya memiliki ciri khas yang spesifik yang tidak dimiliki oleh yang lain. Kemudian jika bahasa dikatakan bersifat unik, maka artinya, setiap bahasa mempuyai ciri khas sendiri yang tidak dimiliki oleh bahasa lainnya. Ciri ini biasa meliputi sistem bunyi, antonasi, atau sistem-sistem lainnya.

\section{Bahasa itu universal}

Bahasa itu universal, Artinya, ada ciri-ciri yang sama yangdimiliki oleh setiap bahasa yang ada di dunia ini. Ciri-ciritersebut merupakan unsur bahasa yang paling umum, yang bias dikaitkan dengan ciri-ciri atau sifat bahasa lainnya. Misalnya bahasa yang terdiri dari huruf vocal dan konsonanjuga setiap bahasa mempunyai satuan-satuan bahasa yang bermakna.

\section{Bahasa itu bersifat produktif}

Kata produktif adalah bentuk ajektif dari kata bendaproduksi. Arti produktif adalah "banyak hasilnya", ataulebih tepat "terusmenerus menghasilkan". Mengapa bahasaitu dikatakan produktif ? Karena mesipun unsurunsurbahasa itu terbatas, tetapi dengan unsurunsur denganjumlah terbatas itu dapat dibuat satuan-satuan bahasa yangjumlahnya idak terbatas, meski secara relative, sesuaidengan sistem berlaku dalam bahasa itu.

\section{Bahasa itu bervariasi}

Mengenai variasi bahasa ini, ada tiga istilah yang perludiketahui yaitu idiolek, dialek, dan ragam. Idiolek adalahvariasi atau ragam bahasa yang bersifat perorangan. Dialekadalah variasi bahasa yang digunakan sekelompok anggotamasyarakat pada suatu tempat atau suatu waktu. ragam atauragam bahasa adalah variasi yang digunakan dalam situasi,keadaaan, atau untuk keperluan teretentu. Misalnya, untuksituasi formal, digunakan bahasa baku.

\section{Bahasa itu bersifat dinamis}

Bahasa adalah satunya milik manusia yang tidak pernah lepas dari segala kegiatan dan gerak manusia sepanjang keberadaan manusia itu, sebagai mahkluk yang berbudayadan bermasyarakat. Oleh karena keterikatan bahasa danmanusia yang dalam kehidupannya di dalam masyarakat kegiatan manusia itu tidak tetap dan selalu berubah-ubah,maka bahasa itu juga ikut berubah, menjadi tidak tetap, menjadi tidak statis. Karena itulah, bahasa itu disebut dinamis.

\section{Bahasa itu manusiawi}

Kita tahu bahwa seluruh makhluk hidup di dunia ini bisa berkomunikasi antara satu dan yang lainnya. Bukan hanya manusia, melainkan hewan juga. Misalnya anjing menggonggong untuk berkomunikasi dengan anjing lainnya, kucing mengeong untuk berkomunikasi dengan kucing lainnya. Namun dari penelitian dari beberapa pakar terhadap alat komunikasi binatang bisa disimpulkan bahwa satuan komunikasi yang dimiliki hewan itu bersifat tetap. Berbeda dengan manusia yang 
berkomunikasi secara dinamis dan produktif. Oleh karena itu bisa disimpulkan bahwa bahasa itu manusiawi, karena bahasa itu hanya milik manusia yang produktif dan dinamis.

\section{DAFTAR RUJUKAN}

Aswaty, F. 2013. Bentuk-bentuk

Kekerasan.http:// www.psikologmalang.com/2013/03/ bentuk-bentuk-kekerasan.html . Diakses03 september 2013.

Aswaty, F. 2013. Definisi Bullying.http:// www.psychologymania.com/2012/06/ definisibullying.html. Diakses 03September 2013. Diakses 03 September 2013

Chaer, A. 2003. Linguistik Umum. Jakarta; PT. Rineka Cipta.

Chaer, A. 2009. Psikolinguistik. Jakarta; PT. Rineka Cipta.

Cherry, K. 2013. What Is Child Psychology? A Brief Overview of ChildPsychology. http:/ /psychology.about.com/od/ developmentalpsychology/a/child-

Galtung, J. 1990. Cultural Violence (Journal of Peace Research). Di unduh 04Oktober 2013

Haryanto.2011. Pengertian Psikologi Menurut Beberapa Ahli.http:/ / belajarpsikologi.com/ pengertian-psikologi/. Diakses 04 September 2013Huraerah, Abu.2012. Kekerasan Terhadap Anak. Bandung; Nuansa Cendekia.

Imania, E. 2013. Pentingnya Sikap Respek Bagi Pendidik Dalam Pembelajaran. Jurnalllmu
Pendidikan,(online), (http://

staff.uny.ac.id). Diakses 01 September 2013

Martono, N.2012. Kekerasan Simbolik di Sekolah. Jakarta; PT. Raja GrafindoPersada.

Megawangi, R. 2009. Pendidikan Karakter. Jakarta: Indonesia Heritage Foundation

Parwadarminto.1991. Kamus Umum Bahasa Indonesia. Jakarta;Balai Pustaka

Polewali, J. 2012. Puluhan Siswa Trauma Sekolah akibat Kekerasan.http:/ / health.kompas.com/read/2012/12/03/ 23310344/

Puluhan.Siswa.Trauma.Sekolah.akibat.Kekerasan. Diakses 29 Nopember 2013.

Rukmorini, R. 2013. Kepsek jadi tersangka penganiayaan siswa.http:// regional.kompas.com/read/2013/11/28/ 2025093/

Kepsek.Jadi.Tersangka.Penganiayaan.Siswa. Diakses 29 nopember 2013.

Savitri, A.2012. Materi Kuliah Psikologi Pendidikan Uny, E-book di unduh tanggal12 Januari 2013.

Syah, M.2008. Psikologi Pendidikan dengan Pendekatan Baru. Bandung;Remaja Rosdakarya

Takdir, M. 2013. Dibentak dan diteriaki membuat anak semakin nakal.

http://intisari-online.com/read/dibentakdan-diteriaki-buat-anak-makinnakal.Diakses 06 Maret 2014. . 2006. Kekerasan Anak di Institusi Pendidikan: Tinjauan Hak atas Pendidikan.

Children's Human Rights Foundation 
56\| Lis Susialwati, Dampak Kekerasan Bahasa Pendidik ..... 